\title{
Perbedaan Asupan Energi, Protein, Zink, dan Perkembangan pada Balita Stunting dan non Stunting
}

\section{The Differences of Energy, Protein, Zinc Intake and Development to Stunting and non-Stunting Toddler}

\author{
Farahiyah Yusni Adani*1 ${ }^{1}$, Triska Susila Nindya ${ }^{1}$
}

\begin{abstract}
ABSTRAK
Latar belakang: Stunting adalah permasalahan gizi yang disebabkan oleh asupan zat gizi yang kurang dalam waktu lama dan/atau penyakit infeksi yang berulang.

Tujuan: Tujuan dari penelitian ini adalah untuk menganalisis perbedaan asupan energi, protein, Zink, dan perkembangan pada balita stunting dan non stunting.

Metode: Penelian ini menggunakan studi cross sectional dengan pendekatan kuantitatif. Sampel terdiri dari 64 balita yang di Kelurahan Manyar Sabrangan Surabaya, balita stunting dan non-stunting masing-masing berjumlah 32. Data dianalisis menggunakan chi square Tets.

Hasil: Balita non-stunting mempunyai asupan energi, protein, zink adekuat yaitu $71,9 \%, 93,7 \%$, dan $71,9 \%$ serta perkembangan sesuai yaitu $75 \%$. Balita stunting mempunyai asupan energi, zink inadekuat yaitu $68,7 \%, 65,6 \%$ dan protein adekuat yaitu $68,7 \%$ serta perkembangan menyimpang yaitu $62,5 \%$. Hasil dari penelitian menunjukkan perbandingan balita stunting dan non stunting adalah ada perbedaan signifikan $(p \leq 0,05)$ pada energi, protein, Zink, dan perkembangan.

Kesimpulan: Balita non-stunting mempunyai asupan energi, protein, Fe, Zink yang tinggi dan stimulasi psikososial serta perkembangan yang baik daripada balita stunting.
\end{abstract}

Kata kunci: stunting, perkembangan balita, Asupan Zat Gizi

\section{ABSTRACT}

Background: Stunting is a nutritional problem caused by inadequate nutrition intake for a long time and/or recurrent infectious diseases.

Objectives: The purpose of this study was to analyze the differences of intake of the energy, protein, Zinc, development in stunting and non-stunting toddler.

Methods: The research was a cross sectional study with quantitative approach. The sample size was 64 toddler in Manyar Sabrangan Sub-district, Surabaya, 32 toddler each stunting and non-stunting were taken by simple random sampling. The data were analyzed using Chi Square Test.

Results: Non-stunting toddlers have an adequate intake of energy, protein, zinc respectively $71.9 \%$, $93.7 \%, 71.9 \%$, meanwhile appropriate development was $75 \%$. Stunting toddlers have an inadequate intake of energy, zinc respectively $68.7 \%, 65.6 \%$ and adequate intake of protein was $68.7 \%$, meanwhile deviance development was $62.5 \%$. The results of this study showed that the comparison of differences between stunting and non-stunting toddler were significant $(p \leq 0.05)$ in energy, protein, Zinc, and development.

Conclusion: Non-stunting toddler have a higher intake of the energy, protein, Zinc, and development rather than stunting toddler.

Keywords: stunting, development toddler, intake nutrient

\footnotetext{
*Koresponden: Farahiyahyusni@gmail.com

${ }^{1}$ Departemen Gizi Kesehatan, Fakultas Kesehatan Masyarakat-Universitas Airlangga
} 


\section{PENDAHULUAN}

Stunting adalah keadaan status gizi yang diukur berdasarkan indeks panjang badan menurut umur $(\mathrm{PB} / \mathrm{U})$ atau tinggi badan menurut umur (TB/U) dengan z-score $<-2 S^{1}$. Stunting dipengaruhi oleh kurangnya gizi kronis disebabkan asupan gizi yang kurang dalam waktu lama ${ }^{2}$.

Permasalahan gizi dengan katagori stunting ini dianggap berat jika prevalensinya sebesar $30-39 \%$ dan serius bila prevalensinya sebesar $\geq 40 \%{ }^{4}$. Prevalensi stunting nasional mencapai 37,2 persen, meningkat dari tahun 2010 (35,6\%), dan 2007 (36,8\%) sedangkan prevalensi status gizi balita di Jawa Timur berdasarkan tinggi badan menurut umur (TB/U) katagori normal sekitar $64,2 \%$, dengan kata lain sisanya yaitu $35,8 \%$ termasuk dalam katagori z-score <-2 SD dengan sebaran 19\% pendek dan $16,8 \%$ sangat pendek ${ }^{3}$. Dampak balita yang mengalami stunting salah satunya dari segi perkembangan yaitu menurunnya perkembangan kognitif, motorik, dan bahasa ${ }^{5}$. Penelitian sebelumnya menunjukkan hubungan antara status gizi TB/ $U$ dengan perkembangan kognitif anak prasekolah ${ }^{6}$. Perkembangan pada balita dapat melalui dua tahapan yaitu tahap sensori-motori yang terjadi pada usia 0-2 tahun dan tahap praoperasional pada usia 2-7 tahun ${ }^{7}$. Balita yang masuk kategori stunting mempunyai asupan energi, protein, dan zink sebagian besar kurang. Ada perbedaan asupan energi dan protein pada kelompok balita stunting dan non stunting di Mesir ${ }^{8}$. Suplementasi zink berpengaruh terhadap pertumbuhan linier yang diujikan pada anak usia 6 bulan ${ }^{9}$.

Prevalensi balita stunting di Surabaya pada tahun 2015 adalah 14.1\% dan Kelurahan Manyar Sabrangan merupakan wilayah dengan prevalensi stunting yang cukup tinggi. Pada tahun 2016 adalah 17,74\% dan meningkat 3,94\% dari tahun 2014. Tujuan penelitian adalah untuk mengetahui perbedaan asupan energi, protein, zink, dan perkembangan balita stunting dan non stunting.

\section{METODE}

Penelitian ini merupakan jenis penelitian observasional dengan desain cross sectional. Sampel dalam penelitian ini adalah balita usia 25-60 bulan di Kelurahan Manyar Sabrangan Surabaya yang memiliki z-score pengukuran status gizi tinggi badan menurut umur yaitu <-2SD atau katagori stunting dan yang mempunyai nilai $z$-score $\geq-2$ SD atau kategori non stunting. Besar Sampel dihitung menggunakan rumus uji hipotesis untuk dua proporsi populasi dengan tingkat kemaknaan 95\% dan kekuatan $90 \%$. Perhitungan tersebut mendapatkan hasil 32 balita masing-masing pada kedua kelompok yang diambil menggunakan simple random sampling.

Pengukuran tinggi badan menggunakan alat microtoise dengan ketelitian $0,1 \mathrm{~cm}$. Asupan makanan balita menggunakan form kuesioner recall 24 jam dalam waktu 2 hari tidak berurutan. Hasil dari dua kali recall tersebut dirata-rata dan dibandingkan dengan cut off point nya yaitu kategori kurang jika < $77 \%$ nilai AKG dan kategori cukup jika $\geq 77 \%$ nilai AKG untuk asupan energi dan protein. Sedangkan untuk asupan zink menggunakan cut off point < EAR untuk kategori kurang dan $\geq$ EAR untuk kategori cukup. Perkembangan balita dinilai dengan menggunakan Kuesioner Pra Skrining Perkembangan (KPSP). Analisis univariat dilakukan untuk melihat distribusi variabel yang diteliti dan karakteristik balita serta keluarga pada kedua kelompok balita stunting dan non stunting. Analisis data bivariat dilakukan untuk melihat perbedaan variabel pada kelompok balita stunting dan non stunting menggunakan uji chi square dengan tingkat kepercayaan $95 \%(\alpha=0,05)$.

Penelitian ini mendapatkan persetujuan komisi etik dari Fakultas Kesehatan Masyaraat dengan nomor 167-KEPK tanggal 2 Mei 2017 dan Bakesbangpol Kota Surabaya dengan nomor 070/4355/436.8.5/2017 tertanggal 4 Mei 2017. Inform consent telah didapatkan dari ibu atau saudara yang mengasuh balita.

\section{HASIL DAN PEMBAHASAN}

Karakteristik balita dan keluarga menunjukkan bahwa paling banyak kelompok balita stunting dan non stunting berusia 25-33 bulan masing-masing yaitu 11 balita $(34,4 \%)$ dan 14 balita $(43,8 \%)$. Hal ini bertentangan dengan penelitian sebelumnya yang dilakukan di Nigeria yang menyatakan bahwa balita 
stunting paling banyak berusia 36-41 bulan yaitu $11,5 \%{ }^{10}$. Penelitian yang dilakukan di Kabupaten Gresik, Indonesia menyatakan bahwa balita stunting paling banyak berusia 25-36 bulan yaitu sebesar $46,2 \%{ }^{11}$. Permasalahan gizi terutama stunting kemungkinan besar paling banyak terjadi pada dua tahun pertama kehidupan. Hal ini berkaitan dengan menyusui dan praktik pemberian makan yang kurang tepat dan kemungkinan akan terus berlanjut saat anak tersebut berusia 36 bulan $^{12}$. Jenis kelamin pada balita stunting paling banyak adalah lakilaki yaitu 20 balita $(62,5 \%)$ sedangkan balita non stunting hampir sama namun cenderung paling banyak perempuan yaitu 17 balita (53,1\%). Penelitian di Aceh dan di China menyatakan bahwa stunting paling banyak berjenis kelamin laki-laki yaitu $50,9 \%{ }^{12},{ }^{13}$. Anak laki-laki cenderung lebih aktif secara fisik sehingga lebih banyak mengeluarkan energi untuk beraktivitas dan tidak untuk pertumbuhannya ${ }^{10}$. Selain itu, pada umumnya laki-laki memiliki pertumbuhan lebih cepat setelah melewati masa pubertas sedangkan pada perempuan umumnya mengalami pertumbuhan yang lebih cepat daripada lakilaki sebelum dan saat masa pubertas ${ }^{14}$. Pendapatan keluarga yang mempunyai balita stunting sebagian besar pada kuartil 1 yaitu 12 keluarga balita $(37,5 \%)$ sedangkan kelompok balita non stunting paling besar pada kuartil 4 yaitu 13 balita (40,6\%). Hal ini sesuai dengan penelitian di Yogyakarta yang menyatakan bahwa pada kelompok balita non stunting paling banyak pendapatan keluarga terletak pada kuartil paling besar yaitu $29.37 \%{ }^{15}$. Pendapatan keluarga merupakan salah satu faktor yang dapat mempengaruhi status ekonomi dan jika status ekonomi rendah dapat berdampak pada ketidakmampuan untuk mendapatkan pangan yang cukup dan berkualitas karena rendahnya daya beli ${ }^{16}$. Jika suatu keluarga mengalami kemiskinan, maka dapat meningkatkan risiko terjadinya diare yang terus berkelanjutan karena kekurangan air bersih dan sanitasi. Diare akan mengganggu fungsi penyerapan didalam usus sehingga dapat mengakibatan balita mengalami pertumbuhan yang terhambat ${ }^{17}$. Tabel 1 menunjukkan bahwa asupan energi pada balita stunting sebagian besar termasuk kategori kurang yaitu 22 balita $(68,8 \%)$ sedangkan pada balita non stunting paling besar termasuk kategori cukup yaitu 23 balita (71,9\%). Terdapat perbedaan yang signifikan asupan energi pada kelompok balita stunting dan non stunting dengan nilai $p$ adalah 0,001 . Hal tersebut sesuai penelitian di Mesir yang menyatakan bahwa adanya perbedaan yang signifikan asupan energi pada kelompok balita stunting dan non stunting ${ }^{8}$. Hal ini dapat menyebabkan kurang energi kronis (KEK) dan jika dalam kurun waktu lama dapat menyebabkan pertumbuhan linier terganggu. Keseimbangan energi yang negatif juga dapat menyebabkan insulin plasma berkurang sehingga dapat menurunkan sintesis Liver Insulin Growth Factor (IGF-1), mempengaruhi kinerja IGF binding protein-1, hormon tiroid, dan faktor sistemik lainnya yang terlibat dalam fibroblast growth factor (FGF-21) yang seluruhnya berperan dalam pertumbuhan linier $^{18}$. Balita stunting dan non stunting sebagian besar mempunyai kategori asupan protein yang sama yaitu cukup walaupun pada balita non stunting mempunyai persentase yang lebih besar yaitu 30 balita (93,8\%) sedangkan pada balita stunting yaitu 22 balita (68,8\%). Terdapat perbedaan yang signifikan asupan protein pada balita stunting dan non stunting dengan nilai $p$ yaitu 0,010 . Hal itu sesuai dengan penelitian yang dilakukan di Kota Pontianak Timur dan Utara ${ }^{19}$ dan Mesir ${ }^{8}$ yang menyatakan bahwa asupan protein signifikan lebih rendah pada anak stunting daripada non stunting. Protein adalah salah satu zat gizi makro yang berfungsi sebagai reseptor yang dapat mempengaruhi fungsifungsi DNA yang mengendalikan proses pertumbuhan dengan mengatur sifat dan karater bahannya (20). Kualitas dan kuantitas asupan protein yang baik dapat berfungsi sebagai Insulin growth factor 1 (IGF-1) yang merupakan mediator dari hormon pertumbuhan dan pembentuk matriks tulang. Asupan protein yang kurang dapat merusak massa mineral tulang dengan cara merusak produksi IGF-1, yang mempengaruhi pertumbuhan tulang dengan merangsang poliferasi dan diferensiasi kondrosit di lempeng epifisi pertumbuhan dan akan 
memengaruhi osteoblas ${ }^{19}$. Jika balita kekurangan asupan protein, ia dapat mengalami gangguan pertumbuhan linier dan mengakibatkan stunting ${ }^{20}$.

Asupan zink pada balita stunting sebagian besar pada kategori kurang yaitu 21 balita $(65,6 \%)$ sedangkan pada balita non stunting sebagian besar pada kategori cukup yaitu 23 balita (71,9\%). Terdapat perbedaan yang signifikan asupan zink pada balita stunting dan non stunting dengan nilai $p$ yaitu 0,003. Ini sejalan dengan penelitian di Thailand dimana terdapat hubungan yang signifikan antara asupan zink yang kurang dengan kejadian stunting ${ }^{21}$. Jika tubuh mengalami defisiensi zink, maka akan terjadi gangguan pada reseptor $\mathrm{GH}$, sehingga resisten terhadap produksi $\mathrm{GH}$, lalu berkurangnya sintesis Liver Insulin Growth Factor (IGF-1) dan protein yang membawanya (binding protein) yaitu IGFBP-322. Pada balita berisiko kekurangan zink lebih besar karena memerlukan zink yang besar untuk proses pertumbuhan yang juga diperlukan pada saat kehamilan, bayi, dan masa pubertas ${ }^{23}$.

Balita stunting dan non stunting sebagian besar mempunyai kategori asupan protein yang sama yaitu cukup walaupun pada balita non stunting mempunyai persentase yang lebih besar yaitu 30 balita $(93,8 \%)$ sedangkan pada balita stunting yaitu 22 balita (68,8\%). Terdapat perbedaan yang signifikan asupan protein pada balita stunting dan non stunting dengan nilai $p$ yaitu 0,010 . Hal itu sesuai dengan penelitian yang dilakukan di Kota Pontianak Timur dan Utara yang menyatakan bahwa asupan protein signifikan lebih rendah pada anak stunting daripada non stunting ${ }^{9,19}$. Protein adalah salah satu zat gizi makro yang berfungsi sebagai reseptor yang dapat mempengaruhi fungsi-fungsi DNA yang mengendalikan proses pertumbuhan dengan mengatur sifat dan karater bahannya ${ }^{20}$. Kualitas dan kuantitas asupan protein yang baik dapat berfungsi sebagai Insulin growth factor 1 (IGF-1) yang merupakan mediator dari hormon pertumbuhan dan pembentuk matriks tulang ${ }^{8}$. Asupan protein yang kurang dapat merusak massa mineral tulang dengan cara merusak produksi IGF-1, yang mempengaruhi pertumbuhan tulang dengan merangsang poliferasi dan diferensiasi kondrosit di lempeng epifisi pertumbuhan dan akan memengaruhi osteoblas ${ }^{19}$. Hal tersebut berarti bahwa jika balita kekurangan asupan protein dapat menyebabkan pertumbuhan linier terganggu dan mengakibatkan stunting. Terdapat perbedaan perkembangan pada balita stunting dan non stunting secara signifikan dengan nilai $p$ yaitu 0,002 . Hal tersebut sesuai dengan penelitian di Bogor yang menyatakan bahwa terdapat hubungan antara status gizi TB/U dengan salah satu aspek perkembangan yaitu kognitif pada anak prasekolah ${ }^{24}$. Perkembangan otak anak yang sensitif terkait dengan asupan zat gizi mayoritas terjadi pada usia dua tahun, dan apabila pada usia dua tahun tersebut terjadi kekurangan asupan zat gizi maka perkembangannya akan terhambat ${ }^{25}$. Sel saraf otak akan terus berkembang sehingga pada usia lima tahun ukuran otak anak telah mendekati ukuran otak orang dewasa, kirakira $90 \%$ sehingga nutrisi yang tepat selama kehamilan dan selama lima tahun usia anak, sangat berperan dalam hasil perkembangan otak $^{26}$. Sebagai contoh adalah asam amino yang terdapat dalam protein dapat berfungsi sebagai prekursor neurotransmitter yang berfungsi sebagai perkembangan otak dan dapat mempengaruhi dalam perkembangan pada anak terutama asam amino tirosin dan triptofan ${ }^{27}$. Sementara itu, salah satu zat gizi mikro yaitu zink dapat berfungsi sebagai pelepasan neurotrasmitter, pematangan, neurogenesis, migrasi neuron dan pembentukan sinaps ${ }^{27}$. Ibu yang kekurangan asupan seng (zink) dapat mempengaruhi penurunan gerakan janin, variabilitas denyut jantung, menurunkan stabilitas sistem saraf otonom, dan menurunkan preferential behavior anak, serta dapat merubah fungsi hipotalamus dalam otak ${ }^{27}$. Balita stunting sebagian besar memiliki perkembangan dengan kategori menyimpang yaitu 20 balita $(62,5 \%)$ sedangkan pada balita non stunting sebagian besar memiliki perkembangan dengan kategori sesuai yaitu 24 balita (75\%). Kelebihan penelitian ini menggunakan instrumen KPSP yang mempunyai tingkat sensitivitas dan spesifisitas yang tergolong tinggi. 
Tabel 1. Asupan pada Balita Stunting dan non Stunting di Kelurahan Manyar Sabrangan 2017

\begin{tabular}{lccccc}
\hline \multirow{2}{*}{ Asupan Balita } & \multicolumn{2}{c}{ Stunting } & \multicolumn{2}{c}{ Non Stunting } & \multirow{2}{*}{ Nilai $\boldsymbol{p}$} \\
\cline { 2 - 5 } & $\mathbf{n}$ & $\%$ & $\mathbf{n}$ & $\%$ & \\
\hline Energi & & & & & \\
$\quad$ Cukup & 10 & 31,3 & 23 & 71,9 & 0,001 \\
$\quad$ Kurang & 22 & 68,7 & 9 & 28,1 & \\
\hline Protein & & & & & \\
$\quad$ Cukup & 22 & 68,7 & 20 & 93,7 & 0,010 \\
$\quad$ Kurang & 10 & 31,3 & 2 & 6,3 & \\
\hline Zink & & & & & \\
Cukup & 11 & 34,4 & 23 & 71,9 & 0,003 \\
$\quad$ Kurang & 21 & 65,6 & 9 & 28,1 & \\
\hline
\end{tabular}

Kekurangan penelitian ini diantaranya desain penelitian cross sectional, instrument food recall 24 hours sehingga tidak bisa menggambarkan riwayat asupan makannya. Hal tersebut karena stunting adalah suatu kondisi kekurangan asupan zat gizi yang terjadi pada masa lampau dan dalam waktu yang lama.

\section{KESIMPULAN}

Asupan energi, protein, dan zink serta tingkat perkembangan mempunyai perbedaan yang signifikan antara balita stunting dan non stunting. Asupan makanan pada balita perlu diperhatikan terutama sumber protein dan zink untuk mencegah dan mengatasi stunting serta meningkatkan perkembangan otak.

\section{ACKNOWLEDGEMENT}

Terima kasih penulis berikan kepada Bakesbangpol Kota Surabaya, Dinkes Kota Surabaya, dan Puskesmas Mulyorejo Surabaya.

\section{REFERENSI}

1. Kementrian Kesehatan RI. Keputusan Kementrian Kesehatan RI tentang Standart Antropometri Penilaian Status Gizi Anak. 2011. Available from http://gizi.depkes.go.id/wp-

content/uploads/2011/11/buku-sk-antropometri2010.pdf. Diakses pada 2 Oktober 2016.

2. MCA-Indonesia. Scalling Up Nutrition (SUN) 1000 hari pertama kehidupan. 2015. Available from http://mca-indonesia.go.id/wp-

content/uploads/2015/01/Backgrounder-StuntingID.pdf. diakses 2 Oktober 2016.

3. Kementrian Kesehatan RI. Riset Kesehatan Dasar. 2013. Available from http://www.depkes.go.id/resources/download/gen
eral/Hasil\%20Riskesdas\%202013.pdf. Diakses 3 Oktober 2016.

4. World health organization. Global Database on Child Growth and Malnutrition. 2010. Available form

http://www.who.int/nutgrowthdb/about/introducti on/en/index5.html. Diakses 30 September 2016

5. World health organization. Childhood Stunting: Context. Causes and Consequences. 2013. Available form

http://www.who.int/nutrition/events/2013_Childh oodStunting_colloquium_140ct_ConceptualFrame work_colour.pdf. Diakses 1 Otober 2016

6. Solihin RDM, Anwar F, Sukandar D. Kaitan Antara Status Gizi, Perkembangan Kognitif, dan Perkembangan Motorik pada Anak Usia Prasekolah. Jurnal Penelitian Gizi dan Makanan 2013; 36(1): 6272. Available form http://ejournal.litbang.depkes.go.id/index.php/pgm /article/view/3396/3387. Diakses 21 Desember 2016.

7. Ibda F. Perkembangan Kognitif: Teori Jean Piaget. Intelektualita 2015; 3(1): 27-38. Available form http://jurnal.ar-

raniry.ac.id/index.php/intel/article/download/197/ 178. Diakses 20 Desember 2016.

8. Mikhail WZA, Sobhy HM, El-sayed HH, Khairy SA, Abusalem HYH, Samy MA. Effect of Nutritional Status on Growth Pattern of Stunted Preschool Children in Egypt. Academic Journal of Nutrition 2013; 2(1): 01-09. Available form http://www.idosi.org/ajn/2(1)13/1.pdf. Diakses 14 Juni 2017.

9. Wessells KR, Brown KH. Estimating the Global Prevalence of Zinc Deficiency: Results Based on Zinc Availability in National Food Supplies and the Prevalence of Stunting. Jurnal Plos One 2012; 7(11): e50568. Available form https://www.ncbi.nlm.nih.gov/pmc/articles/PMC35 
10072/pdf/pone.0050568.pdf. Diakses 3 Maret 2017.

10.Akomibi BJ, Akho KE, Hall JJ, Merom D, AstellBurt T, Renzaho AMN. Stunting and severe stunting among children under-5 years in Nigeria: $A$ multilevel analysis. BMC Pediatrics 2017; 17(15): 1-16. Available form https://www.ncbi.nlm.nih.gov/pmc/articles/PMC52 37247/pdf/12887_2016_Article_770.pdf. Diakses 14 Juni 2017.

11.Welasasih BD, Wirjatmadi RB. Beberapa Faktor yang Berhubungan dengan Status Gizi Balita Stunting. The Indonesian Journal of Public Health 2012; 8(3): 99-104. Available form http://www.journal.unair.ac.id/filerPDF/2.\%20Bebe rapa\%20Faktor\%20yang\%20Berhubungan\%20deng an.pdf. Diakses 20 Desember 2016.

12.Zhang J, Shi J, Himes JH, Du Y, Yang S, Shi S, Zhang J. Undernutrition status of children under 5 years in Chinese rural areas - data from the National Rural Children Growth Standard Survey. Asia Pasific J Clin Nutrition 2011; 20(4): 584-592. Available form http://apjcn.nhri.org.tw/server/APJCN/20/4/584.pd f. Diakses 14 Juni 2017.

13.Lestari W, Margawati A, Rahfiludin MZ. Faktor Risiko Stunting pada Anak Umur 6-24 Bulan di Kecamatan Penanggalan Kota Subulussalam Provinsi Aceh. Jurnal Gizi Indonesia 2014; 3(1): 37$45 . \quad$ Available form http://ejournal.undip.ac.id/index.php/jgi/article/vie wFile/8752/7081. Diakses 10 Juni 2017.

14.Adriani M, Wirjatmadi B. Peranan Gizi dalam Siklus Kehidupan. Jakarta: Kencana Prenadamedia Group; 2014. P. 177-180.

15.Amin NA, Julia M. Faktor Sosiodemografi dan Tinggi Badan Orang Tua serta Hubunganya dengan Kejadian Stunting pada Balita Usia 6-23 Bulan. Jurnal Gizi dan Dietetik Indonesia 2014; 2(3): 170$177 . \quad$ Available form http://ejournal.almaata.ac.id/index.php/IJND/articl e/view/299/271. Diakses 22 Desember 2016.

16.Anugraheni HS, Kartasurya MI. Faktor Risiko Kejadian Stunting Pada Anak Usia 12-36 Bulan Di Kecamatan Pati, Kabupaten Pati. Journal of Nutrition College 2012; 1(1): 30-37. Available form http://ejournal-s1.undip.ac.id/index.php/jnc.

Diakses 15 Juni 2017.

17. Guerrant RL, Deboer MD, Moore SR, Scharf RJ, Lima AAM. The improverished gut a Triple Burden of diarrhoea, Stunting and Chronic Disease. Nature Reviews Gastroenterology and Hepatology 2013; 10(4): 220-229. Available form https://www.ncbi.nlm.nih.gov/pmc/articles/PMC36 17052/pdf/nihms-448036.pdf. Diakses 15 Juni 2017.

18. Yablonski GG, Phillip M. Nutritionally-Induced Catch Up Growth. Nutrients 2015; 7: 517-551. Available form www.mdpi.com/journal/nutrients. Diakses 14 Juni 2017.

19.Sari EM, Juffrie M, Nurani N, Sitaresmi MM. Protein, calcium and phosphorus intake of stunting and non stunting children aged 24-59 months. Jurnal Gizi Klinik Indonesia 2016; 12(4): 152-159. Available form

https://journal.ugm.ac.id/jgki/article/viewFile/2311 1/15588. Diakses 14 Juni 2017.

20.Budiyanto MAK. Dasar Dasar Ilmu Gizi. Malang: UMM Pres; 2004. P. 40-41.

21.Gibson RS, Manger MS, Krittaphol W, Pongceharoen T, Gowachirapant S, Bailey KB, Winichagoon P. Does zinc deficiency play a role in stunting among primary school children in NE Thailand. British Journal of Nutrition 2007;97(1):167-175. Available form https:/www.cambridge.org/core/terms. Diakses 14 Juni 2017.

22.Agustian L, Sembiring T, Ariani A. Peran Zinkum terhadap Pertumbuhan Anak. Sari Pediatri 2009; 11(4): 244-249. Available form http://saripediatri.idai.or.id/pdfile/11-4-4.pdf . Diakses 9 April 2017.

23. Roohani N, Hurrell R, Kelishadi R, Schulin R. Zinc and its importance for human health: An integrative review. Journal of Research in Medical Sciences 2013;18(1):144-157. Available form http://www.jrms.mui.ac.ir/files/journals/1/articles/ 8963/public/8963-36461-1-PB.pdf. Diakses 14 Juni 2017.

24.Solihin RDM, Anwar F, Sukandar D. Kaitan Antara Status Gizi, Perkembangan Kognitif, dan Perkembangan Motorik pada Anak Usia Prasekolah. Penelitian Gizi dan Makanan 2013; 36 (1): 62-72. Available form http://ejournal.litbang.depkes.go.id/index.php/pgm /article/view/3396/338. Diakses 28 Oktober 2016.

25.Wachs TD, Georgieff M, Cusick S, McEwen B. Issues in the Timing of Integrated Early Interventions: Contributions from Nutrition, Neuroscience and Psychological Research. Annals of the New York Academy of Sciences 2014; 1308: 89-106. Available form

https://www.ncbi.nlm.nih.gov/pmc/articles/PMC40 75015/pdf/nihms565175.pdf . Diakses 2 Juli 2017.

26.Diana FM. Omega 3 dan Kecerdasan Otak. Jurnal Kesehatan Masyarakat 2013; 7(2): 82-88. Available form

jurnal.fkm.unand.ac.id/index.php/jkma/article/view /113/119. Diakses 5 Oktober 2016.

27.Georgieff MK. American Society for Clinical Nutrition Nutrition and the developing brain: nutrient priorities and measurement. The American Journal of Clinical Nutrition 2007; 85(2): 614-620. 